Original Article

\title{
SELF MEDICATION PRACTICE AMONG URBAN SLUM DWELLERS IN UDUPI TALUK, KARNATAKA, INDIA
}

\author{
PRANAV V.* , PRAKASH NARAYANAN, VASUDEVA GUDDATTU \\ Department of Public Health, Manipal University, Manipal, Karnatka \\ Email: pranav.vy@gmail.com
}

Received: 30 Oct 2016 Revised and Accepted: 20 Apr 2017

\section{ABSTRACT}

Objective: To estimate the prevalence and associated factors of self-medication among slum dwellers, and to explore the perception of community pharmacists' on self-medication practices in Udupi taluk of Karnataka state in India.

Methods: A quantitative survey among 300 randomly selected slum dwellers and in-depth interviews with community pharmacists and pharmacy practice experts were conducted during January-April 2016. Descriptive and analytical methods were used to estimate the prevalence and to identify associated factors. Thematic analysis was carried out on qualitative data.

Results: The prevalence of self-medication practice was $47 \%$. Factors such as gender, recent experience of an illness, and stocking medicines at home were significantly associated with self-medication practice. Self-medication practices were high for common ailments and for the illnesses they perceived as 'mild' (66\%). Community pharmacists (87\%) were the main source of information on medication. The majority (76\%) of participants were ignorant about the expiry date of the medicines. The qualitative data highlighted pharmacist's' role to promote consultation with a physician, and educating patients on completion of treatment course and possible drug reactions.

Conclusion: Self-medication practices found to be common among slum-dwellers due to reasons such as lesser awareness, easy availability of overthe-counter medications, and limitations related to universal access to health. There is a need to improve the awareness of dangers of selfmedication to the general public and strengthen the mechanism to monitor dispensing of medicines without prescriptions.

Keywords: Over the counter (OTC) drugs, Self-medication, Slum dwellers, Udupi

(C) 2017 The Authors. Published by Innovare Academic Sciences Pvt Ltd. This is an open access article under the CC BY license (http://creativecommons.org/licenses/by/4.0/) DOI: http://dx.doi.org/10.22159/ijpps.2017v9i6.15950

\section{INTRODUCTION}

Self-medication is a human behaviour, defined as the use of medication by a person to treat his or her own illness/ailment and the usage of a previously prescribed drug for a chronic or recurrent disease or symptoms, without the consultation of a registered medical practitioner and surveillance of treatment $[1,2]$. Despite having its own demerits, self-medication is an important health policy component of primary health care and patient empowerment [3]. Self-medication could be beneficial for the patients, healthcare providers, and pharmaceutical industry if practices appropriately as it reduces the pressure on the healthcare system, saves time and stands as a strong alternative to treat ailments $[3,4]$.

An interesting point noted was that some of the drugs that could be purchased only with the prescriptions in developed countries could be purchased over the counter (OTC) in developing countries. World Health Organization (WHO) emphasized that the practice should be controlled [5, 6]. In India, the Drugs and Cosmetics Act of 1940, the Drugs and Cosmetics Rules of 1945 regulates the import, manufacture, distribution and sale of drugs and cosmetics, and that OTC has no legal implications in India. Several studies have shown that, although the OTC drugs used for self-treatment were considered as safe and efficacious, the lack of awareness on their dosage, side effects, and interactions could lead to inappropriate practices which may have serious implications in geriatrics, pediatrics and in conditions like pregnancy and lactation [7]. The most common problems associated with self-medication were the development of drug resistance, pathogenic resistance, drug-drug interactions and complications due to adverse drug reactions, polypharmacy and prolonged illness $[4,8]$ It is the obligation of the Government and health authorities to promote responsible self-medication practices, ensure the quality and safety of over the counter drugs, and to inform the consumers on the usage of drugs [5]. The concept of 'responsible self-medication' introduced by the WHO aimed at promoting rational use of medicines through proper drug information, and adequate labeling in the package and inclusion of information leaflets [9]. Slum dwellers are considered as one of the most socioeconomically deprived population. In the developing countries like India due to easy availability of drugs and inadequate healthcare services, many of the drugs are dispensed over the counter without medical supervision. This could lead the increased use of self-medication drugs compared to prescribed drugs. As of now, there are no legal implications and regulations for the OTC drugs in India [10].

A cross-sectional study was conducted among urban slum dwellers in Udupi taluk of Karnataka state in India to estimate the prevalence and factors associated with self-medication, as well as to explore the perception of community pharmacists regarding self-medication practices of slum dwellers.

\section{MATERIALS AND METHODS}

A community-based cross-sectional study was conducted among randomly selected urban slum dwellers of Udupi taluk in Udupi district of Karnataka state in India, during January to April 2016. The list of slums (total 23 slums), which was procured from Udupi City Municipal Council and a two-stage cluster sampling approach was adopted. Random selection of 10 slums as the first stage and systematic random selection of 30 households from selected slums in the second stage. One eligible and consented respondent from each selected household was considered for the study. A participant information sheet which contains all relevant information about the study was explained and the written consent was obtained from participants who were willing to be part of the study. Ethical permission for the study was obtained from the Institutional Ethical Committee of Kasturba Medical College and Kasturba Hospital on $12 / 01 / 2016$. The registration number was of the ethics committee is ECR/146/Inst/KA/2013 and IEC number of the study is 31/2016.

In order to calculate the sample size, a pilot study was conducted in few urban slums in Udupi taluk and the estimated prevalence of self- 
medication was $85 \%$. Considering a margin error of $5 \%$ and a design effect of 1.5 , the required sample size for the study was calculated as 300 .

The analysis was carried out in SPSS16. The prevalence of selfmedication and its relation with health status and treatment seeking behaviors were assessed. Pearson's Chi-square or Fisher's exact (if the cell value is less than 5) tests were performed to measure the associations. All tests were double-sided and a p-value lesser than 0.05 was considered as statistically significant. Five in-depth interviews were conducted among community pharmacists and academicians to explore their perceptions regarding the reasons for self-medication, dangers of self-medication and the responsibilities of community pharmacists in self-medication.

\section{RESULTS}

The study was conducted among 300 randomly selected slum dwellers in Udupi taluk. As shown in fig. 1, the prevalence of the selfmedication practice among study participants was found to be $47 \%$.

The table 1 provides the socio-demographic characteristics of the study participants and their associations with self-medication practice. Majority of the study participants were males (58\%), has a mean age of $36 \mathrm{y}$, were currently married (90\%), belonged to Hindu religion (91\%), did not have school education (59\%), were working as daily wage labourers (95\%), and belonged to the daily income category of Indian Rupees 300-500 (62\%).

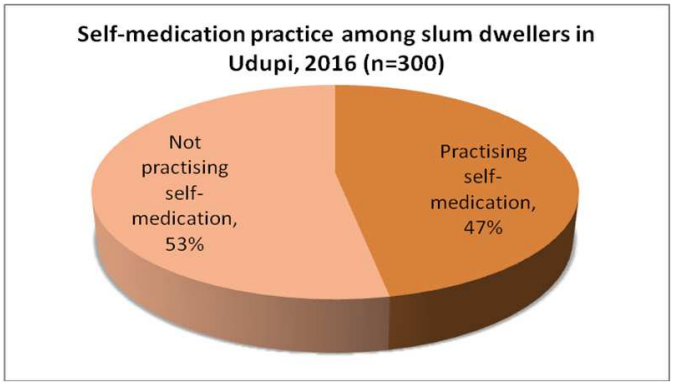

Fig. 1: Prevalence of self-medication practices among slum dwellers, $n=300$

Among those practicing self-medication, higher proportions were males $(65 \%)$, had a mean age was $35.4 \mathrm{y}$, were currently married (90\%), from Hindu religion (91\%), had no schooling (58\%), engaged as daily wage labour $(94 \%)$, and earns an income in the range of Indian Rupees 300-500 a day. As compared to females, a higher proportion of males were practicing self-medication $(57 \%$ of males vs. $39 \%$ females, $p=0.026$ ). No significant associations were observed between socio-demographic factors of the study participants and self-medication practices in this study.

Table 1: Socio-demographic factors, and their association to self-medication practices among slum dwellers in Udupi, 2016 ( $n=300$ )

\begin{tabular}{|c|c|c|c|c|c|c|c|}
\hline \multirow[t]{2}{*}{ Variables } & \multicolumn{2}{|c|}{ All subjects $(n=300)$} & \multicolumn{2}{|c|}{ Practicing self-medication ( $n=141)$} & \multicolumn{2}{|c|}{ Not practicing self-medication $(n=159)$} & \multirow[t]{2}{*}{ p-value } \\
\hline & Count & Col \% & Count & Col \% & Count & Col \% & \\
\hline \multicolumn{8}{|l|}{ Gender } \\
\hline Male & 175 & 58.3 & 92 & 65.2 & 83 & 52.2 & 0.026 \\
\hline Female & 125 & 41.7 & 49 & 34.8 & 76 & 47.8 & \\
\hline \multicolumn{8}{|l|}{ Age (in years) } \\
\hline $18-26$ & 72 & 24.2 & 38 & 27.3 & 34 & 21.4 & 0.331 \\
\hline $27-33$ & 74 & 24.8 & 36 & 25.9 & 38 & 23.9 & \\
\hline $34-43$ & 76 & 25.5 & 29 & 20.9 & 47 & 29.6 & \\
\hline 44 above & 76 & 25.5 & 36 & 25.9 & 40 & 25.2 & \\
\hline Mean age $( \pm S D)$ & $36.3(12.4)$ & & $35.4(12.3)$ & & $37.1(12.4)$ & & 0.205 \\
\hline \multicolumn{8}{|l|}{ Marital status } \\
\hline Married & 269 & 89.7 & 127 & 90.1 & 142 & 89.3 & 0.279 \\
\hline Single & 19 & 6.3 & 11 & 7.8 & 8 & 5.0 & \\
\hline Separated/widowed & 12 & 4.0 & 3 & 2.1 & 9 & 5.7 & \\
\hline \multicolumn{8}{|l|}{ Religion } \\
\hline Hindu & 272 & 90.7 & 128 & 90.8 & 144 & 90.6 & 0.992 \\
\hline Muslim & 26 & 8.7 & 12 & 8.5 & 14 & 8.8 & \\
\hline Christian & 2 & 0.7 & 1 & 0.7 & 1 & 0.6 & \\
\hline \multicolumn{8}{|l|}{ Education } \\
\hline Illiterate & 176 & 58.7 & 82 & 58.2 & 94 & 59.1 & 0.622 \\
\hline Primary school & 93 & 31.0 & 45 & 31.9 & 48 & 30.2 & \\
\hline Secondary school & 27 & 9.0 & 11 & 7.8 & 16 & 10.1 & \\
\hline Graduation & 4 & 1.3 & 3 & 2.1 & 1 & 0.6 & \\
\hline \multicolumn{8}{|l|}{ Occupation } \\
\hline Daily labourers & 286 & 95.3 & 133 & 94.3 & 153 & 96.3 & 0.436 \\
\hline Skilled workers & 14 & 4.7 & 8 & 5.7 & 6 & 3.8 & \\
\hline \multicolumn{8}{|c|}{ Daily income (Indian Rupees) } \\
\hline Less than Rs. 150 & 5 & 1.6 & 3 & 2.1 & 2 & 1.3 & 0.682 \\
\hline Rs. $150-300$ & 70 & 23.3 & 30 & 21.3 & 40 & 25.2 & \\
\hline Rs.300-500 & 185 & 61.6 & 91 & 64.5 & 94 & 59.1 & \\
\hline More than Rs. 500 & 40 & 13.3 & 17 & 12.1 & 23 & 14.5 & \\
\hline
\end{tabular}

Self-medication related practices of 141 self-medication practitioners are depicted in table 2. Major reasons for selfmedication reported by the respondents were mild illness $(65.9 \%)$ and cost saving related to travel and consultations (24.1\%). Major health conditions for which self-medication practiced were head/body ache $(40.3 \%)$, common cold $(33.3 \%)$, fever $(20.3 \%)$ and cough $(14.7 \%)$. For a majority $(87.2 \%)$ of the participants, community pharmacists provided information on the drugs for selfmedication. The first criteria for selection of the medicines for selfmedication were the indication of use $(55.3 \%)$ and price of medication (35.4\%). More than $90 \%$ of those practicing selfmedication described their symptoms to the pharmacist to procure the medicines $(90.7 \%)$ and received necessary information on drug dosage from the pharmacists $(91.5 \%)$. 
Table 2: Practices related to self-medication among slum dwellers in Udupi, 2016 ( $n=141)$

\begin{tabular}{|c|c|c|}
\hline Practices & Count & Col \% \\
\hline \multicolumn{3}{|l|}{ Main reason for practicing self-medication } \\
\hline Mild nature of illness & 93 & 65.9 \\
\hline Cost saving in consultations and travel & 34 & 24.1 \\
\hline Doctors/health facility is far away & 9 & 6.3 \\
\hline Lack of time & 5 & 3.5 \\
\hline \multicolumn{3}{|c|}{ Conditions which the self-medication is practiced* } \\
\hline Head and/or body ache & 121 & 40.3 \\
\hline Cold & 100 & 33.3 \\
\hline Fever & 61 & 20.3 \\
\hline Cough & 44 & 14.7 \\
\hline Respiratory diseases and/or allergy & 13 & 9.2 \\
\hline \multicolumn{3}{|c|}{ Source of information about the drugs for self-medication } \\
\hline Community pharmacist & 123 & 87.2 \\
\hline Opinion from friends or family members & 10 & 7.0 \\
\hline Media advertisements & 4 & 2.8 \\
\hline Previous prescriptions by doctors & 3 & 2.1 \\
\hline Others & 1 & 0.7 \\
\hline \multicolumn{3}{|c|}{ Criteria for the selection of specific medicines in self-medication } \\
\hline Indication of use & 78 & 55.3 \\
\hline Price of medication & 50 & 35.4 \\
\hline Brand of medication & 8 & 5.6 \\
\hline Type of medication & 5 & 3.5 \\
\hline \multicolumn{3}{|c|}{ Method of procuring self-medication drugs from a pharmacy } \\
\hline Described the symptoms of the illness & 128 & 90.7 \\
\hline Mention the name of the drug & 12 & 8.5 \\
\hline Show old prescription & 1 & 0.7 \\
\hline \multicolumn{3}{|c|}{ Source of information on the self-medication drug dosage } \\
\hline Pharmacist & 129 & 91.5 \\
\hline Family members and the Internet & 10 & 7.1 \\
\hline Doctor & 2 & 1.4 \\
\hline
\end{tabular}

*-Multiple responses possible, the percentages may add to more than 100 .

Table 3: Univariate association between health condition, treatment seeking behaviour and self-medication

\begin{tabular}{|c|c|c|c|c|c|c|c|}
\hline \multirow[t]{2}{*}{$\begin{array}{l}\text { Health and health care seeking } \\
\text { behaviour }\end{array}$} & \multicolumn{2}{|c|}{$\begin{array}{l}\text { All subjects } \\
(n=300)\end{array}$} & \multicolumn{2}{|c|}{$\begin{array}{l}\text { Practicing self-medication } \\
(n=141)\end{array}$} & \multicolumn{2}{|c|}{$\begin{array}{l}\text { Not practicing self-medication } \\
(n=159)\end{array}$} & \multirow[t]{2}{*}{ p-value } \\
\hline & Count & Col \% & Count & Col \% & Count & Col \% & \\
\hline \multicolumn{8}{|c|}{ Experienced illness within past $30 \mathrm{~d}$} \\
\hline Yes & 107 & 35.7 & 59 & 41.8 & 48 & 30.2 & \multirow[t]{2}{*}{0.035} \\
\hline No & 193 & 64.3 & 82 & 58.2 & 111 & 69.8 & \\
\hline \multicolumn{8}{|c|}{ Stock medicines for minor illness or emergency at home } \\
\hline Yes & 117 & 39.0 & 100 & 70.9 & 17 & 10.7 & \multirow[t]{2}{*}{$<0.001$} \\
\hline No & 183 & 61.0 & 41 & 29.1 & 142 & 89.3 & \\
\hline \multicolumn{8}{|c|}{ Frequency of examining the instructions in drug package label } \\
\hline Always & 53 & 17.7 & 3 & 2.1 & 50 & 31.4 & \multirow[t]{3}{*}{0.727} \\
\hline Sometimes & 18 & 6.0 & 7 & 4.9 & 11 & 6.9 & \\
\hline Never & 229 & 76.3 & 131 & 92.9 & 98 & 61.7 & \\
\hline \multicolumn{8}{|c|}{ Ever verified the expiry date of drugs } \\
\hline Yes & 71 & 23.6 & 31 & 22.0 & 40 & 25.2 & \multirow[t]{2}{*}{0.519} \\
\hline No/Do not remember & 229 & 76.3 & 110 & 78.0 & 119 & 74.8 & \\
\hline \multicolumn{8}{|c|}{ Frequency of dosage change practice during the course of treatment } \\
\hline Yes, always & 147 & 49.0 & 99 & 70.1 & 48 & 30.2 & \multirow[t]{3}{*}{$<0.001$} \\
\hline Sometimes & 26 & 8.7 & 10 & 7.1 & 16 & 10.1 & \\
\hline Never & 127 & 42.3 & 32 & 22.7 & 95 & 52.7 & \\
\hline \multicolumn{8}{|c|}{ Ever experienced adverse drug reactions because of self-medication } \\
\hline Yes & 13 & 4.3 & 11 & 7.8 & 2 & 1.3 & \multirow[t]{2}{*}{0.005} \\
\hline No & 287 & 95.7 & 130 & 92.2 & 157 & 98.7 & \\
\hline \multicolumn{8}{|c|}{ Perception about self-medication practice } \\
\hline Acceptable & 120 & 40.3 & 116 & 82.3 & 4 & 2.5 & \multirow[t]{2}{*}{0.430} \\
\hline Not acceptable & 179 & 59.7 & 25 & 17.7 & 154 & 96.8 & \\
\hline \multicolumn{8}{|c|}{ Ever practiced self-medication along with physician prescribed medications } \\
\hline Yes & 141 & 47.0 & 50 & 35.4 & 91 & 57.2 & \multirow[t]{2}{*}{$<0.001$} \\
\hline No & 159 & 53.0 & 91 & 64.5 & 68 & 42.7 & \\
\hline
\end{tabular}

The table 3 depicts health condition of the respondents, their treatment seeking behaviour and its association with self-medication. of the 300 participants, about $36 \%$ has experienced an illness in past one month, almost half (47\%) used self-medication along with medicines prescribed by the physician, almost two-third (39\%) has the habit of stocking medicines for minor illness or emergency at their home, more than three-fourth (76\%) never verified expiry date of drugs, almost half (49\%) frequently changed drug dosage during the treatment course, less than $5 \%$ had experienced adverse drug reactions due to self-medication, and three-fifth (60\%) perceived the practice of self-medication as 'not acceptable'.

In comparison to those persons who were not practising selfmedication, significant differences were observed among those who 
self-medicate on factors such as: have had an illness in past month (42\% among those self-medicate versus $30 \%$ among others, $\mathrm{p}=0.035$ ), stored medicines for minor illness or emergency at their home $(71 \%$ vs. $11 \%, \mathrm{p}<0.001)$, frequently changed medication dosage during the treatment course $(70 \%$ vs. $30 \%, p<0.001)$ and experienced adverse drug reactions due to self-medication $(4.3 \% \mathrm{vs}$. $1.3 \%, p=0.005$ ). Comparatively lesser number of self-medication practitioners did the practice self-medication along with physician prescribed medicines than others ( $35 \%$ vs. $57 \%, \mathrm{p}<0.001)$.

The perception of community pharmacists and academicians regarding self-medication practice among the slum dwellers were captured through qualitative in-depth interviews. All the participants were of the opinion that self-medication is a common practice among the slum dwellers and the practice is growing. The issues such as lack of awareness about nearby healthcare providers and facilities, affordability, scarcity of time to avail treatment, urge for faster cure of illness, poverty, loss of work/wage upon availing treatment from crowded health facilities, and possible absence of physicians in public health facilities has emerged as contributing factors for self-medication practices among urban poor living in slums. The qualitative interview participants were concerned about the dangers of self-medication and were of the opinion that the pharmacists should promote patients' consultations with physicians, educating customers on correct dosage and side-effects of medicines.

\section{DISCUSSION}

The prevalence of the practice of self-medication among slum dwellers in Udupi taluk of Karnataka state in India estimated through this study was $47 \%$. The practice of self-medication was commonplace for mild ailments and illness such as head and body ache, cold, fever and cough. Medicines for self-medication were procured by describing the symptoms of the ailment to the community pharmacists. A higher proportion of self-medication practitioners were found to be males, those suffered from an illness in past month and have had the habit of storing medicines at home. A considerable proportion of self-medication practitioners has experienced adverse drug reactions.

The studies conducted among slum community in India have shown varying estimates of self-medication practices $[3,10]$. The variations could be due to regional differences in socio-economic factors, healthcare seeking behaviors and availability and accessibility to health care facilities. Similar to other studies conducted in India, this study also has shown that self-medication practices were more common for the illnesses such as head and body ache, common cold and fever, which the participants believed as mild $[1,3-5,8,13,14]$. As reported in similar studies, the pharmacists were found to be the main source of information on medicines [10]. The criteria used for selection of medicines were the indication of use and price. Poverty coupled with lack of knowledge, loss of wage, time and associated cost to access and avail health care services, overcrowding at health care facilities and higher costs of physician consultations and prescribed medications found to be the reason for self-medication [7]. Slum dwellers need quick recovery from their illnesses so that they could go back to their work.

The habit of using of over-the-counter drugs along with the prescribed medications as well as changing dosage regimen during the course of medication found among the participants that can lead to drug-drug interactions, drug resistance, pathogenic resistance and increased morbidity. Only a smaller proportion of slum dwellers knew about the importance of expiry date of medicines they purchase, and to assess expiry date of the medicines [7]. The majority of the participants remarked that self-medication is not acceptable and harmful, and a few have had the experience of adverse drug reaction due to self-medication.

\section{CONCLUSION}

The prevalence of self-medication practices among slum dwellers participated in this study (47\%) was slightly higher compared to other studies. This study showed the importance and necessity to assess and monitor the self-medication practices among vulnerable population groups such as slum dwellers. Though the majority of the participants perceived self-medication practice non-acceptable, it was a common practice for milder illnesses, those suffered from a recent illness and who possessed prescriptions, and those who stocked medicines at home. People like slum dwellers in India usually seek a faster solution to health problems and cannot afford to spare much time and money to seek health care. So the risks associated with self-medication also be more among poorly informed people like slum dwellers and illiterates.

Commercial availability of a range of medicines through the wider network of community pharmacies in India, where the pharmacist usually suggest drugs and dosage based on narrated signs and symptoms and affordability of customers. Many people used to procure and store medicines for minor illness at home for future use in emergencies. The majority of those who practice self-medication never verify expiry date of drugs frequently changes the dosage regimen during the treatment and often experienced adverse drug reactions.

Health education to the public on consequences of self-medication and importance of responsible use of medicines may help the people to use medicines in a better way. There is a need to enforce laws to discourage dispensing the medicines without prescriptions. It is important to educate pharmacists on enforcing the importance of observing prescribed dosage till treatment completion to all customers, and particularly to those practices self-medication. The public health program managers could consider providing healthcare services by prolonged consultation hours and offer services convenient to daily wage workers in overcrowded facilities.

The findings of the study should be viewed in cautiously as the analysis was based on self-reported self-medication practice in past one month, and the medicines or the health conditions of the respondents could not be verified systematically during data collection. This study was conducted only in slum areas, and the practices might not be similar in other places and population groups.

\section{CONFLICT OF INTERESTS}

\section{Declared none}

\section{REFERENCES}

1. Donkor E, Tetteh Quarcoo P, Nartey P, Agyeman I. Selfmedication practices with antibiotics among tertiary level students in accra, ghana: a cross-sectional study. Int J Environ Res Public Health 2012;9:3519-29.

2. Eickhoff C, Hämmerlein A, Griese N, Schulz M. Nature and frequency of drug-related problems in self-medication (overthe-counter drugs) in daily community pharmacy practice in Germany. Pharmacoepidemiol Drug Saf 2012;21:254-60.

3. Gupta P, Bophate S, Shrivastava R. Determinants of selfmedication practices in an urban slum community. Asian J Pharm Clin Res 2011;4:54-7.

4. Valley K. Self-medication practice among undergraduate pharmacy students in, Kathmandu Valley, Nepal. Int J Pharm Sci Res 2014;5:737-46.

5. Verma RK, Mohan L, Pandey M. Evaluation of self-medication among professional students in North India: proper statutory drug control must be implemented. Asian J Pharm Clin Res 2010;3:60-4.

6. Patel MM, Singh U, Sapre C, Salvi K, Shah A, Vasoya B. Selfmedication practices among college students: a cross-sectional study in Gujarat. Natl J Med Res 2013;3:257-60.

7. Kulkarni P, Khan M, Chandrasekhar A. Self-medication practices among Urban Slum dwellers in the south Indian city. Int J Pharma Bio Sci 2012;3:81-7.

8. Gutema GB, Gadisa DA, Abebe Z, Berhe DF, Berhe AH, Hadera G, et al. Self-medication practices among health sciences students: the case of mekelle university. Appl Pharm Sci 2011;1:183-9.

9. Kumar V, Mangal A, Yadav G, Raut D, Singh S. Prevalence and pattern of self-medication practices in an urban area of Delhi, India. Med J Dr DY Patil Univ 2015;8:16.

10. Durgawale PM. The practice of self-medication among slumdwellers. Indian J Public Health 1998;42:53-5.

11. Olayemi OJ, Olayinka BO, Musa. Evaluation of antibiotic selfmedication pattern amongst undergraduate students of 
ahmadu bello university (Main Campus), zaria. Res J Appl Sci Eng Technol 2010;2:35-8.

12. Varghese S, Durgawale PM, Mathew P. Prevalence of selfmedication in an urban slum area in Maharashtra. J Krishna Inst Med Sci Univ 2013;2:108-10.

13. Goel D, Gupta S. Self-medication patterns among nursing students in North India. IOSR J Dental Med Sci 2013; 11:14-7.
14. Osmene KP, Lamikanra A. A study of the prevalence of self medication practice among university students in southwestern Nigeria. Trop J Pharm Res 2012;11:683-9.

\section{How to cite this article}

- Pranav V, Prakash Narayanan, Vasudeva Guddattu. Selfmedication practice among urban slum dwellers in udupi taluk karnataka, India. Int J Pharm Pharm Sci 2017;9(6):19-23. 